\title{
Insecticidal activity of culture filtrates from liquid medium of Beauveria bassiana isolates from South Sumatra (Indonesia) wetland soil against larvae of Spodoptera litura
}

\author{
DWI RIZKI AYUDYA ${ }^{1}$, SITI HERLINDA ${ }^{2,3, \vartheta}$, SUWANDI SUWANDI $^{2,3}$ \\ ${ }^{1}$ Crop Sciences Graduate Program, Faculty of Agriculture, Universitas Sriwijaya. Palembang 30139, South Sumatra, Indonesia \\ ${ }^{2}$ Department of Plant Pests and Diseases, Faculty of Agriculture, Universitas Sriwijaya. Indralaya 30662, South Sumatra, Indonesia \\ ${ }^{3}$ Research Center for Sub-optimal Lands (PUR-PLSO), Universitas Sriwijaya. Jl. Padang Selasa No. 524, Palembang 30139, South Sumatra, Indonesia. \\ Tel./Fax.: +62-711-352879, vemail: sitiherlinda@unsri.ac.id
}

Manuscript received: 22 June 2019. Revision accepted: 7 July 2019.

\begin{abstract}
Ayudya DR, Herlinda S, Suwandi S. 2019. Insecticidal activity of culture filtrates from liquid medium of Beauveria bassiana isolates from South Sumatra (Indonesia) wetland soil against larvae of Spodoptera litura. Biodiversitas 20: 2101-2109. The obstacle in utilizing entomopathogenic fungi to control pest insects in wetlands is the inability of their isolates to survive during the saprophytic phase due to the soil being very acidic. Therefore, the exploration of fungi being able to survive in the acidic soil was utilized in the acidic ecosystem. This study aimed to test the toxic activity of Beauveria bassiana culture filtrates from liquid medium at $\mathrm{pH} 2.5$ and 6 against Spodoptera litura larvae. Total of ten isolates collected from South Sumatra, Indonesia was grown in liquid media at $\mathrm{pH}$ of 2.5 and 6 for six weeks. The result showed that the culture filtrate from liquid medium at $\mathrm{pH} 6$ was more toxic against the larvae than that at $\mathrm{pH}$ 2.5. The mortality of the larvae at $\mathrm{pH} 6$ reached $92 \%$, while that at $\mathrm{pH} 2.5$ it reached $13.33 \%$ only. The findings of present study revealed that the culture filtrate isolates of BPdR, BJgTs, BSwTd2, BSwTd3, BSwTd4, BKKPp2 from pH 2.5 media still caused high larvae mortality $(6.67-13.33 \%)$. These seven isolates are superior due to their toxic nature at $\mathrm{pH} 2.5$. Consequently, present study has increased the chances of success in utilizing these isolates for biological control in acidic ecosystems, such as peatlands, tidal lowlands, and freshwater swamps.
\end{abstract}

Keywords: Capsicum annuum, entomopathogenic fungus, mortality, $\mathrm{LT}_{50}, \mathrm{LT}_{90}$

\section{INTRODUCTION}

Indonesia wetlands are characterized by an ecosystem covering 9.2 million hectares of freshwater swamps, 11 million hectares of tidal lowlands, and 14.9 million hectares of peatlands and spreading in Sumatra, Kalimantan, and Papua islands (Mulyani and Sarwani 2013). Soil of wetlands is generally submerged during certain months of the year and the difference in immersion time causes the specific plants that are planted (Safitri et al. 2018). Freshwater swamps are generally planted with rice, chili, and other vegetables, and tidal lowlands are also planted with rice but more intensive (two-three indexes) compared to that of freshwater swamps (one index) (Herlinda et al. 2018b). While peatlands are rarely planted with annual crops, they are usually used for oil palm plantation (Dohong et al. 2018), forestry and conservation areas.

The Indonesia wetland soil is generally varied, particularly viewed from the aspects of soil moisture, texture, and $\mathrm{pH}$. Soil texture of freshwater swamps is silt dominant (mud) which is silt sedimentation from the river flow, and contains balanced clay and sand (Kartika et al. 2018), the tidal lowlands contain silt of a mixture of river and sea water deposits, the clay and sand content remains balanced (Marlina et al. 2016), the peat soil does not contain clay, sand, and the silt contains only organic matter (Mulyani and Sarwani 2013). The freshwater swamp soil contains pH ranging from 4 to 4.5 (Kodir and Juwita, 2016), the tidal lowlands containing $\mathrm{pH}$ between 4.17-5.35 (Marlina et al. 2016), and in the peatlands $\mathrm{pH}$ ranging from 3.60-3.95 (Utami et al. 2009).

Entomopathogenic fungi are those of soil parasitizing and killing insects pest and proved superior in biological control. However, Beauveria bassiana and Metarhizium anisopliae are two examples of entomopathogenic fungi (Herlinda et al. 2018a), whose utilization is often constrained by external factors (Sumikarsih et al. 2019). B. bassiana is facultative parasites that can be parasitic on insects and saprophytes in soil or organic matter. Soil $\mathrm{pH}$ variations of each ecosystem can affect the ability of adaptation of entomopathogenic fungi as saprophytes (Bugeme et al. 2008). The too acidic $\mathrm{pH}$ medium, though grows both fungi, but can reduce the viability and density of conidia, even kill the fungi (Rizkie et al. 2017) and reduce the fungal biodiversity in the soil (Safitri et al. 2018). However, there are still species or isolates of the fungi conidia still survive at $\mathrm{pH} 2$ (Rizkie et al. 2017). According to Pinnamaneni et al. (2010), the minimum $\mathrm{pH} 4$ is generally required by $B$. bassiana which enables these fungi to produce chitinase enzymes that can kill host insects. The $\mathrm{pH}$ range of the culture medium used for growing B. bassiana under acidic is at (4.0), neutral at (7.0), and basic at (11.0) (Qazi 2008). The results of the previous studies on wetland soils in South Sumatra depicted the acidic $\mathrm{pH}$ potential of inoculum of $B$. bassiana 
and $M$. anisopliae from peat soil as compared to those of freshwater swamps and tidal lowlands (Safitri et al. 2018), yet the effectiveness of these fungi against insect pests is still unknown. The main insect pests mostly attack chili (Capsicum annuum L.) and other specific vegetables grown in wetlands (Johari et al., 2014, 2016). Isolates of entomopathogenic fungi able to survive and still effective at extremely low $\mathrm{pH}$ are superior isolates that have the potential as biological agents that can be utilized and expected to survive saprophytically on the soil of the wetlands ecosystem. The objective of this research was to test the toxic activity of $B$. bassiana culture filtrates from liquid medium at $\mathrm{pH} 2.5$ and 6 against the larvae of Spodoptera litura.

\section{MATERIALS AND METHODS}

\section{Study area}

The study was conducted at the Laboratory of Entomology, Department of Plant Pests and Diseases, Faculty of Agriculture, Universitas Sriwijaya, Indralaya from October 2018 to March 2019. The average temperature during the experiment was $29.60{ }^{\circ} \mathrm{C}$ and relative humidity was $82.34 \%$. All $B$. bassiana isolates used in this experiment were explored from the wetlands South Sumatra, Indonesia (Figure 1) as the results of the exploration carried out by Safitri et al. (2018). In this study, the Spodoptera litura were selected as tested insects because they found to attack the vegetable plants commonly grown on wetlands most dominantly.

\section{Test insect preparation}

The larvae of Spodoptera litura were collected from chili and other vegetables are grown without the application of synthetic insecticides at the Experimental Farm of the Faculty of Agriculture, Universitas Sriwijaya. Then the larvae of $S$. litura were taken to the laboratory and kept in a plastic jar $(15 \mathrm{~cm} \times 25 \mathrm{~cm})$ carefully at room temperature. a chili plant was inserted into the jar to feed $S$. litura larvae which were then maintained until the second generation.

The growing larvae were transferred into another jar already provided with fresh chili every day. Every day the larvae were moved into another jar. When the final instar larvae entered the pupa phase, they were moved into a plastic jar having been provided with soil $(10 \mathrm{~cm}$ thick) which was already sterilized in the oven for 1 hour at $100^{\circ} \mathrm{C}$. Chili plants were also provided in this jar to facilitate egg-laying of $S$. litura adults which started to appear from the pupae.

The eggs were laid by the adults on the underside of the leaves. Four days later the egg colonies were transferred into other jars already provided with new fresh chili leaves to feed newly hatched larvae. The mass-rearing was carried out to obtain the second generation culture. The one-day second instar larvae were used for test insects of this study.

\section{Preparation of Beauveria bassiana isolates}

The isolates were first made fit using a modified method of Herlinda (2010). For preparation of culture media, in $16.2 \mathrm{~g}$ of Sabouraud Dextrose Agar (SDA, Merck) $250 \mathrm{ml}$ aquadest was added, sterilized in an autoclave for 120 minutes at a pressure of 1 atm and poured was poured into a $10 \mathrm{ml}$ Petri dish $(9 \mathrm{~cm}$ diameter) under aseptic conditions of laminar airflow and allowed to solidify. Then $B$. bassiana was cultured on solidified culture media (SDA) along with the Tenebrio molitor larvae.
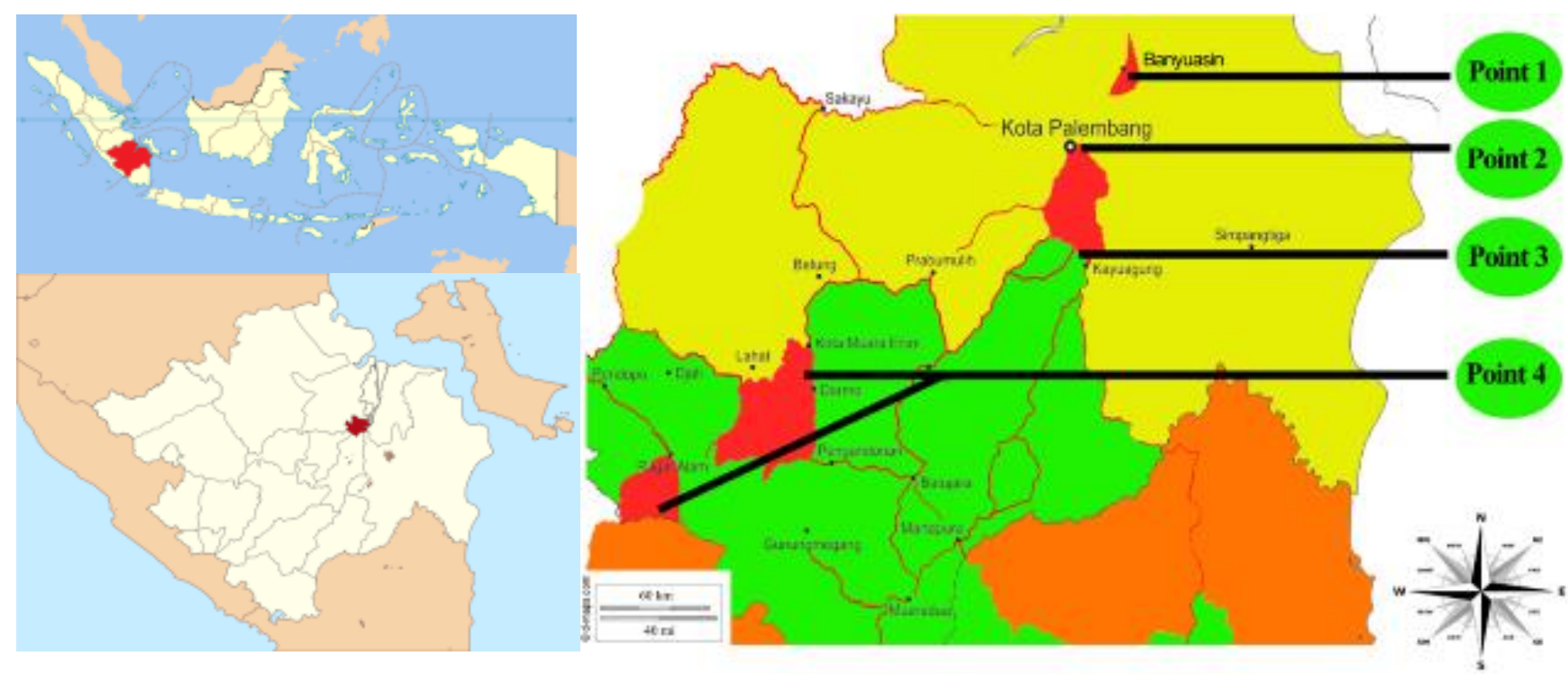

Figure 1. Locations of Beauveria bassiana isolates exploration from wetland soil in South Sumatra, Indonesia. Point 1: Tidal lowlands, Point 2: Freshwater swamps, Point 3: Peatlands, Point 4: Highlands (Safitri et al. 2018) 


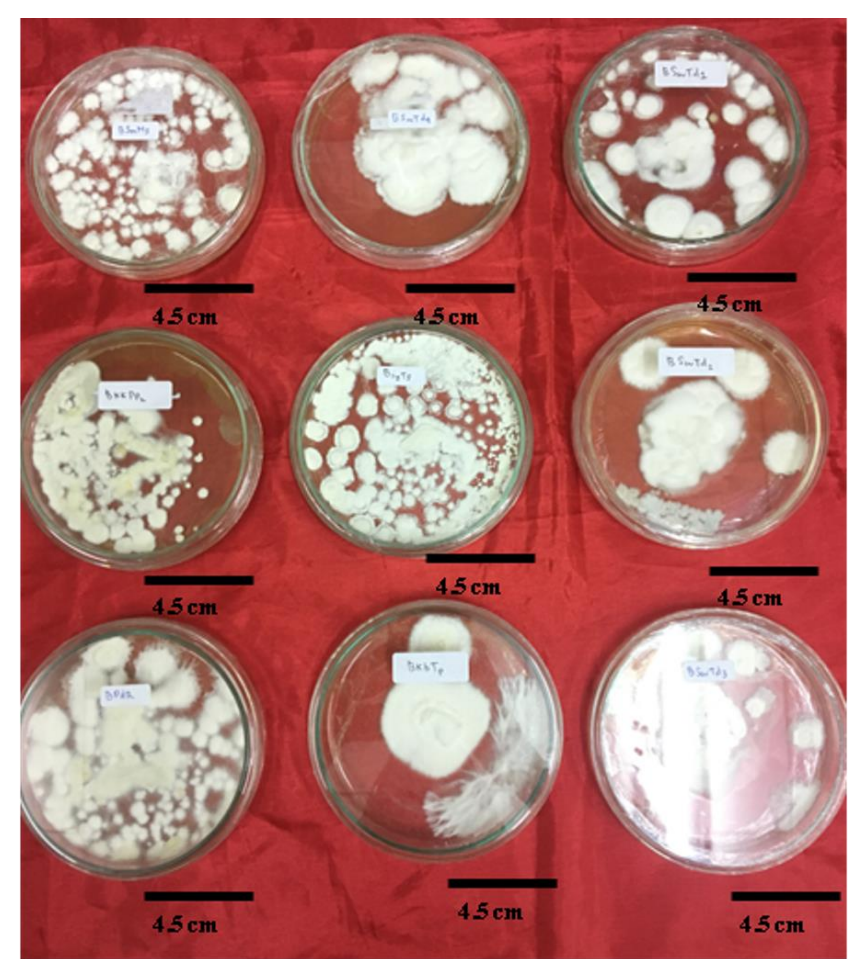

Figure 2. Beauveria bassiana SDA culture incubated for 7 days

Table 1. Isolates identity of Beauveria bassiana used in this research

\begin{tabular}{llll}
\hline $\begin{array}{c}\text { Code of } \\
\text { isolate }\end{array}$ & Ecosystems & $\begin{array}{l}\text { Vegetation or } \\
\text { crop plants }\end{array}$ & Village or city \\
\hline BPdR & $\begin{array}{l}\text { Freshwater } \\
\text { swamps }\end{array}$ & Paddy & Rambutan \\
& Tidal lowlands & Corn & Telang Sari \\
BJgTs & Tidal lowlands & Watermelon & Mulya Sari \\
BSmMs & Peatlands & Oil palm & Talang Dabok \\
BSwTd1 & Peatlands & Oil palm & Talang Dabok \\
BSwTd2 & Peatlands & Oil palm & Talang Dabok \\
BSwTd3 & Peatlands & Oil palm & Talang Dabok \\
BSwTd4 & Highlands & Rubber and & Pulau Pinang \\
BKKPp2 & coffee & Talang Patai \\
\hline
\end{tabular}

\section{Preparation of culture filtrate}

About one-week old isolates of entomopathogenic fungi isolated from SDA media (Figure 2) were then grown in PDB (Potato Dextrose Broth) media. The media composition of PDB consisted of $20 \mathrm{~g}$ dextrose monohydrate, $200 \mathrm{~g}$ peeled potatoes, and $1,000 \mathrm{ml}$ aquadest. Before being extracted, the potatoes were first to cut into cubes with a size of $\pm 2 \mathrm{~cm}$, and boiled using 1,000 $\mathrm{ml}$ aquadest for 20 minutes. Then, the $\mathrm{pH}$ of PDB medium was regulated using the method of (Rizkie et al. 2017) by dripping the medium with $32 \% \mathrm{HCl}$ as many as 1 to 8 drops with $10 \mu \mathrm{l}$ micropipette until reaching the $\mathrm{pH} 2.5$. Meanwhile, to get $\mathrm{pH} 6$, the PDB medium was dripped with $\mathrm{NaOH} 1$ mole as many as 1 to 8 drops with $10 \mu \mathrm{l}$ micropipette until it reached the $\mathrm{pH} 6$. Based on the consideration of the soil in the wetlands, the determination of the treatment of $\mathrm{pH} 2.5$ and 6 was $\mathrm{pH}<3$, whereas the $\mathrm{pH} 6$ was the ideal $\mathrm{pH}$ for fungal growth (Qazi 2008). About $150 \mathrm{ml}$ liquid medium was poured into a heatresistant glass bottle (volume $300 \mathrm{ml}$ ) and sterilized into an autoclave for 120 minutes at a pressure of $1 \mathrm{~atm}$. After being cooled, B. bassiana culture was inoculated in this PDB medium for 6 weeks.

\section{Production of culture filtrate}

Six weeks old culture broth of each $B$. bassiana isolates was then filtered to separate extracts from hyphae, mycelia, and conidia. Two stages of filtration method was adapted with slight modification (Cheong 2015). The purpose of separation from hyphae, mycelia, and conidia was to get a culture filtrate containing toxic insecticidal compounds. In first stage of filtration, $100 \mathrm{ml}$ of $B$. bassiana culture on the SDB was poured into an Erlenmeyer tube (volume of 500 $\mathrm{ml}$ ) whose tube mouth was fitted with Whatman filter paper number 42 cotton-coated $1 \mathrm{~cm}$ thick and produced \pm $70 \mathrm{ml}$ coarse culture filtrate. The coarse culture filtrate was filtered using a syringe filter $(0.45 \mu \mathrm{m}-25 \mathrm{~mm})$ conducted in second stage filtration as follows: $1 \mathrm{ml}$ of the first stage coarse culture filtrate was sucked using a hypodermic needle (volume of $6 \mathrm{ml}$ ) and then the needle was removed and the base of the needle was attached a syringe filter. Then the needle was attached back to the hypodermic needle and $1 \mathrm{ml}$ of crude culture filtrate was filtered using a syringe filter to obtain the culture filtrate. The culture filtrates were used at a concentration of the original preparation without dilution by sterile water.

\section{Isolates activity insecticidal test of Beauveria bassiana}

$1 \mathrm{ml}$ culture filtrates obtained in second filtration was dropped onto the chili leaves; then these leaves were infested with test insects (the second instar of $S$. litura larvae) as many as 25 test insects per isolate for 6 hours and repeated three times. Before being treated, the test insects were left unfed for 2 hours and weighed using a Portable Jewelry Scale (capacity of $30 \mathrm{~g} \mathrm{x} 0.01 \mathrm{~g}$ ). After 6 hours of infestation and ensuring that all larvae ate the leaves moistened with the culture filtrate $B$. bassiana, the test insects were moved into a plastic cylinder (the top of which was covered with gauze) in which there were 5 new chili leaves (without culture filtrate of $B$. bassiana). Every $1 \times 24$ hours the dead larvae were recorded and the chili leaves were replaced and the area of the eaten leaves, the weight of the feces, and the larvae body weight were measured. The observations of these variables were carried out for 12 days.

To measure the percentage of the foliar damage area caused by the insects, a bioleaf application as given by Machado et al. (2016) was used. The area of chili leaves before being eaten was measured using the formula of Widuri et al. (2017) as follows:

$$
\mathrm{ILD}=0.606 \times \mathrm{P} \times \mathrm{L}
$$

ILD: Index of leaf area $\left(\mathrm{cm}^{2}\right)$; P: leaf length; L: leaf width 
Defoliation is the percentage of leaves eaten by the insects. Defoliation was measured using the following formula:

$$
\mathrm{LDD}=\mathrm{D} \times \mathrm{ILD}
$$

LDD: Area of eaten leaves; D: Defoliation

\section{Data analysis}

Differences in data on body weight and feces, and the area of eaten leaves among the isolates are shown in a graphical form. Mortality and time of death of the test insects $\left(\mathrm{LT}_{50}\right)$ were analyzed using analysis of variance (ANOVA). Tukey's Honestly Significant Difference (HSD) Test was employed to test for significant difference among the treatments (isolates) at $\mathrm{P}=0.05 . \mathrm{LT}_{50}$ and $\mathrm{LT}_{90}$ values were calculated by using probit analysis. All data were analyzed using software of SAS University Edition 2.7 9.4 M5.

\section{RESULTS AND DISCUSSION}

\section{Insecticidal activity of Beauveria bassiana}

The culture filtrates of nine $B$. bassiana isolates already produced from liquid media both incubated at $\mathrm{pH} 2.5$ and pH 6 showed different lethal or toxicity capabilities towards S. litura larvae (Table 2). The culture filtrates produced from culture media with $\mathrm{pH} 6$ showed that the larvae mortality increased sharply from day 4 to 12 , whereas at $\mathrm{pH} 2.5$ the mortality of new test larvae occurred on day 9 and did not increase sharply (Figure 3). On the twelfth day after being applied with the culture filtrates incubated at pH 6 medium, the mortality of tested larvae reached $92 \%$, while those applied with the culture filtrates incubated at $\mathrm{pH} 2.5$ medium only reached $13.33 \%$. Therefore, the $\mathrm{pH}$ on the culture medium of $B$. bassiana could affect the level of toxicity of the culture filtrate. On the last day of observation, the culture filtrates of nine $B$. bassiana isolates from culture medium at $\mathrm{pH} 6$ showed high toxicity to isolate BPdR, BJgTs, BSmMs, BSwTd2, BSwTd4, BKKPp2 and significantly different from controls (Table 2). However, the culture filtrates of nine $B$. bassiana isolates from the culture medium at $\mathrm{pH} 2.5$, all of which had lower toxicity compared to culture filtrates from culture medium at $\mathrm{pH}$ 6. The highest toxicity at $\mathrm{pH} 2.5$ was found in BPdR isolates, BJgTs, BSmMs, BSwTd2, BSwTd3, BSwTd4, and BKKPp2. Yet, although they were cultured on a medium at $\mathrm{pH} 2.5$, the isolates were still quite toxic to the test insects.

The color of culture filtrate from culture media with $\mathrm{pH}$ 6 and 2.5 also showed significant differences (Figure 4). The color of the culture filtrate of $\mathrm{pH} 6$ culture media was generally dark brown, while the $\mathrm{pH} 2.5$ was light brown. The most striking color of the culture filtrate isolates of BPdR, BJgTs, BSmMs, BSwT2, BSwTd4, and BKKPp2 of the $\mathrm{pH} 6$ culture media was more brown than those of $\mathrm{pH}$ 2.5. If these data were related to the mortality data (Table
2), the isolates which gave rise to the dark brown color of culture filtrate resulted in a higher mortality rate.

After applying the culture filtrates of nine isolates of $B$. bassiana from the $\mathrm{pH} 6$ medium, the $\mathrm{LT}_{50}$ and $\mathrm{LT}_{90} S$. litura larvae were shorter than those of $\mathrm{pH} 2.5$ (Table 3). Meanwhile, after applying the culture filtrates from the $\mathrm{pH}$ 6 medium, the $\mathrm{LT}_{50} S$. litura larvae showed an effect that was not significantly different among the isolates, as well as the $\mathrm{LT}_{50}$ which was applied the culture filtrates of $\mathrm{pH}$ 2.5 medium. After applying the culture filtrates from $\mathrm{pH} 6$ medium, the $\mathrm{LT}_{90}$ of $S$. litura larvae showed significantly different effects among the isolates. The $\mathrm{LT}_{90}$ was found the shortest in BJgTs isolates, while the longest one was found in BSwTd3 isolates. After applying the culture filtrates from $\mathrm{pH} 2.5$ medium, the $\mathrm{LT}_{90}$ of $S$. litura larvae showed no significant difference among the isolates.

\section{The effects of Beauveria bassiana culture filtrates on larval growth}

The results of effects of $B$. bassiana culture filtrates from $\mathrm{pH} 6$ or $\mathrm{pH} 2.5$ medium on leaf eaten area (Figure 5) revealed that weight of feces (Figure 6), and weight of larvae (Figure 7) showed similar trends. The older the larvae age was, the wider the leaves were eaten, and the more weight of feces the larvae per animal becomes. The larvae fed with the controlled leaves (not applied to the culture filtrates $B$. bassiana) ate chili leaves most widely and produced most waste. The weight of all treated larvae, except the control ones, showed a tendency to begin to decline on the sixth day. After 12 days of application, the weight of the larvae treated with the culture filtrates $B$. bassiana from pH 6 medium decreased their weight sharply and the lowest weight reached below $0.5 \mathrm{~g} / \mathrm{head}$. The weight of larvae fed with the treatment of culture filtrates from $\mathrm{pH} 2.5$ medium also decreased, but the lowest weight was still above $1 \mathrm{~g} /$ head after 12 days of application. The larvae weight in the control group, both at $\mathrm{pH} 6$ and $\mathrm{pH} 2.5$ media, continued to increase until the end of the observation (after 12-day application).

The larvae of $S$. litura applied to a culture filtrates $B$. bassiana from a $\mathrm{pH} 6$ or $\mathrm{pH} 2.5$ medium showed the same symptoms; 1 x 24 hours after consuming the treatment leaves, the larvae movement became less active as compared to larvae ate the control leaves. The larvae bodies that were applied to culture filtrates of $\mathrm{pH} 6$ and $\mathrm{pH}$ 2.5 tended to be smaller than those of the control. The dead larvae as a result of the applied culture filtrates showed symptoms such as dry, wrinkled, stiff like a mummy, and dull integument body (Figure 8), and they did not smell. In addition, the mouth of the dead larvae secreted green liquid. These dead larvae were checked to find out whether their death due to $B$. bassiana spore infection or due to toxic compounds contained in the culture filtrates, by putting these dead larvae into the SDA media. After 7 days of being incubated in the SDA medium, all of the dead insects did not show the infection caused by spores of $B$. bassiana. Therefore, the death of $S$. litura larvae in this study was caused by the toxin compounds contained in the culture filtrates. 
Table 2. Mortality of larval Spodoptera litura at 4, 8, 12 days after being infested with Beauveria bassiana culture filtrates from medium at $\mathrm{pH} 2.5$ and 6

\begin{tabular}{|c|c|c|c|c|c|c|}
\hline \multirow{3}{*}{ Code of isolate } & \multicolumn{6}{|c|}{ Mortality of Spodoptera litura larvae (\%) } \\
\hline & \multicolumn{2}{|c|}{4 days } & \multicolumn{2}{|c|}{8 days } & \multicolumn{2}{|c|}{12 days } \\
\hline & pH 2.5 & pH 6 & pH 2.5 & pH 6 & pH 2.5 & pH 6 \\
\hline BPdR & 0.00 & $5.33^{\mathrm{a}}$ & 0.00 & $34.67^{\mathrm{bc}}$ & $8.00^{\mathrm{b}}$ & $73.33^{b}$ \\
\hline BJgTs & 0.00 & $5.33^{\mathrm{a}}$ & 0.00 & $46.67^{\mathrm{c}}$ & $6.67^{\mathrm{b}}$ & $92.00^{\mathrm{b}}$ \\
\hline BSmMs & 0.00 & $8.00^{\mathrm{b}}$ & 0.00 & $32.00^{\mathrm{bc}}$ & $6.67^{\mathrm{b}}$ & $85.33^{\mathrm{b}}$ \\
\hline BSwTd1 & 0.00 & $1.33^{\mathrm{a}}$ & 0.00 & $22.67^{\mathrm{b}}$ & $0.00^{\mathrm{a}}$ & $46.67^{\mathrm{ab}}$ \\
\hline BSwTd2 & 0.00 & $2.67^{\mathrm{a}}$ & 0.00 & $28.00^{\mathrm{bc}}$ & $8.00^{\mathrm{b}}$ & $73.33^{\mathrm{b}}$ \\
\hline BSwTd3 & 0.00 & $2.67^{\mathrm{a}}$ & 0.00 & $26.67^{\mathrm{bc}}$ & $6.67^{\mathrm{b}}$ & $40.00^{\mathrm{ab}}$ \\
\hline BSwTd4 & 0.00 & $5.33^{\mathrm{a}}$ & 0.00 & $30.67^{b c}$ & $13.33^{\mathrm{b}}$ & $65.33^{b}$ \\
\hline BKKPp2 & 0.00 & $5.33^{\mathrm{a}}$ & 0.00 & $33.33^{\mathrm{bc}}$ & $8.00^{\mathrm{b}}$ & $73.33^{b}$ \\
\hline BKbTp & 0.00 & $0.00^{\mathrm{a}}$ & 0.00 & $25.33^{\mathrm{b}}$ & $0.00^{\mathrm{a}}$ & $48.00^{\mathrm{ab}}$ \\
\hline Kontrol & 0.00 & $0.00^{\mathrm{a}}$ & 0.00 & $0.00^{\mathrm{a}}$ & $0.00^{\mathrm{a}}$ & $0.00^{\mathrm{a}}$ \\
\hline ANOVA F-value & - & $3.07^{*}$ & - & $19.77^{*}$ & $8.55^{*}$ & $5.33^{*}$ \\
\hline$P$ value $(0.05)$ & - & 0.02 & - & 0 & 0 & 0 \\
\hline Tukey's HSD test & - & 15.5 & - & 12.8 & 13.3 & 50.2 \\
\hline
\end{tabular}

Note: * significantly different; values within a column (the data of each isolate) followed by the same letters were not significantly different at $\mathrm{P}<0.05$ according to Tukey's HSD test. Original data were transformed using Arcsin transformation prior to statistical analysis

Table 3. $\mathrm{LT}_{50}$ and $\mathrm{LT}_{95}$ of larval Spodoptera litura caused by Beauveria bassiana culture filtrates from medium at $\mathrm{pH} 2.5$ and 6

\begin{tabular}{lcccc}
\hline \multirow{2}{*}{ Code of isolate } & \multicolumn{2}{c}{ LT $_{\mathbf{5 0}}$ (days) \pm SD } & \multicolumn{2}{c}{ LT $_{\mathbf{9 0}}$ (days) \pm SD } \\
\cline { 2 - 5 } & $\mathbf{p H ~ 2 . 5}$ & $\mathbf{p H ~ 6}$ & $\mathbf{p H ~ 2 . 5}$ & pH 6 \\
\hline BPdR & $14.83 \pm 0.44$ & $9.71 \pm 0.81$ & $17.35 \pm 0.53$ & $14.11 \pm 1.38^{\mathrm{ab}}$ \\
BJgTs & $14.82 \pm 0.45$ & $8.28 \pm 0.45$ & $17.15 \pm 0.58$ & $11.63 \pm 0.60^{\mathrm{a}}$ \\
BSmMs & $15.36 \pm 0.99$ & $9.19 \pm 0.48$ & $18.37 \pm 1.68$ & $13.50 \pm 1.52^{\mathrm{ab}}$ \\
BSwTd1 & - & $11.49 \pm 0.54$ & - & $16.67 \pm 0.87^{\mathrm{ab}}$ \\
BSwTd2 & $15.06 \pm 0.34$ & $10.24 \pm 1.11$ & $18.10 \pm 0.41$ & $14.51 \pm 1.94^{\mathrm{ab}}$ \\
BSwTd3 & $14.66 \pm 0.74$ & $11.89 \pm 0.36$ & $17.52 \pm 1.20$ & $17.20 \pm 0.66^{\mathrm{b}}$ \\
BSwTd4 & $14.05 \pm 0.17$ & $10.03 \pm 0.48$ & $16.76 \pm 0.44$ & $15.03 \pm 0.37^{\mathrm{ab}}$ \\
BKKPp2 & $14.97 \pm 0.60$ & $9.59 \pm 0.80$ & $17.95 \pm 1.05$ & $14.06 \pm 1.30^{\mathrm{ab}}$ \\
BKbTp & - & $11.52 \pm 1.09$ & - & $16.55 \pm 1.56^{\mathrm{ab}}$ \\
Control & - & - & - & - \\
ANOVA F-value & $0.49^{\text {ns }}$ & $2.72^{\mathrm{ns}}$ & $0.38^{\mathrm{ns}}$ & $2.55^{*}$ \\
P value (0.05) & 0.80 & 0.05 & 0.88 & 0.04 \\
Tukey's HSD test & - & - & - & 6.38 \\
\hline
\end{tabular}

Note: $\mathrm{ns}=$ not significantly different; $*$ = significantly different; values within a column (the data of each isolate) followed by the same letters were not significantly different at $\mathrm{P}<0.05$ according to Tukey's HSD test. Original data were transformed using Arcsin transformation prior to statistical analysis
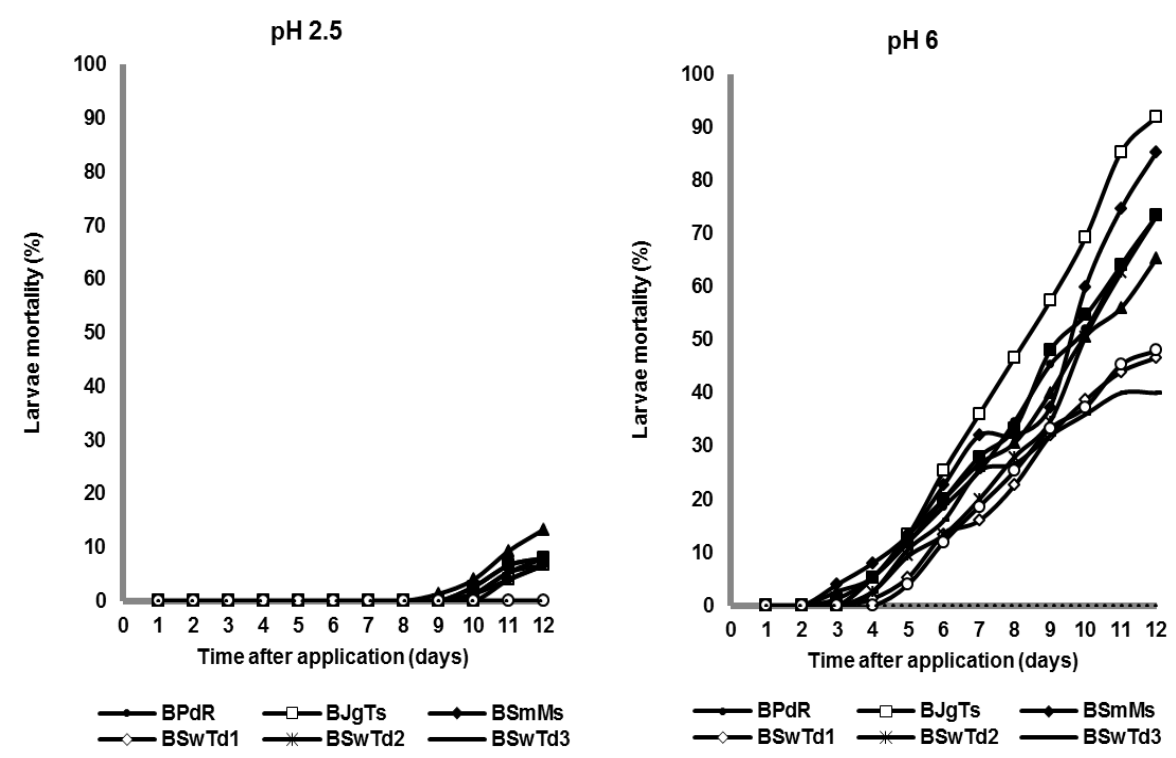

Figure 3. Mortality of Spodoptera litura larvae 


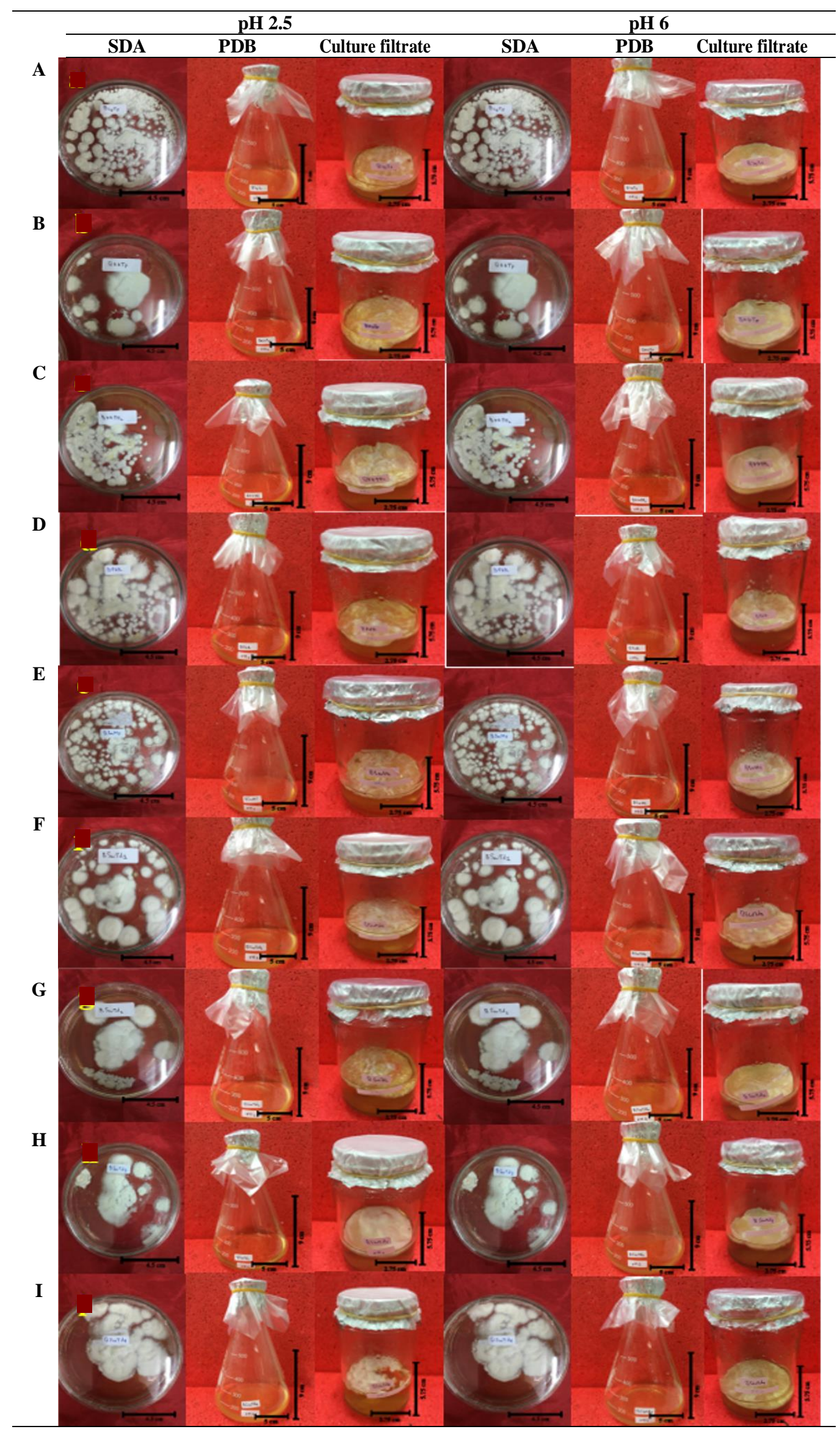

Figure 4. Beauveria bassiana isolates cultured in SDA, PDB, and culture filtrate: A. BPdR, B. BJgTs, C. BSmMs, D. BSwTd1, E. BSwTd2, F. BSwTd3, G. BSwTd4, H. BKKPp2, I. BKbTp 
$\mathrm{pH} 2.5$

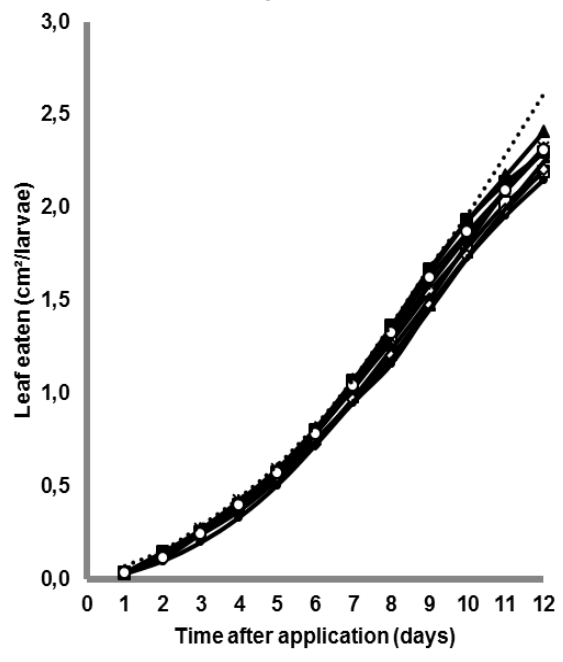

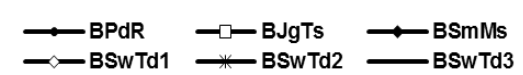

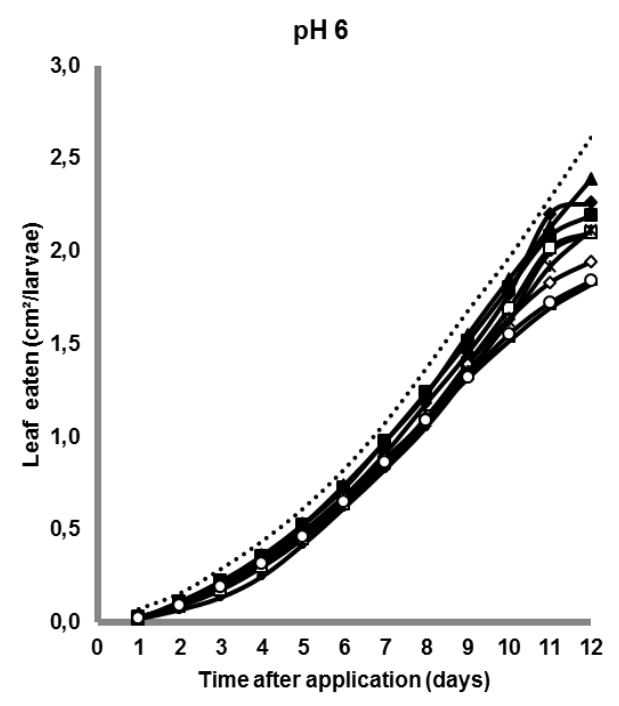

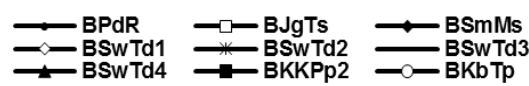

Figure 5. Leaf eaten by Spodoptera litura
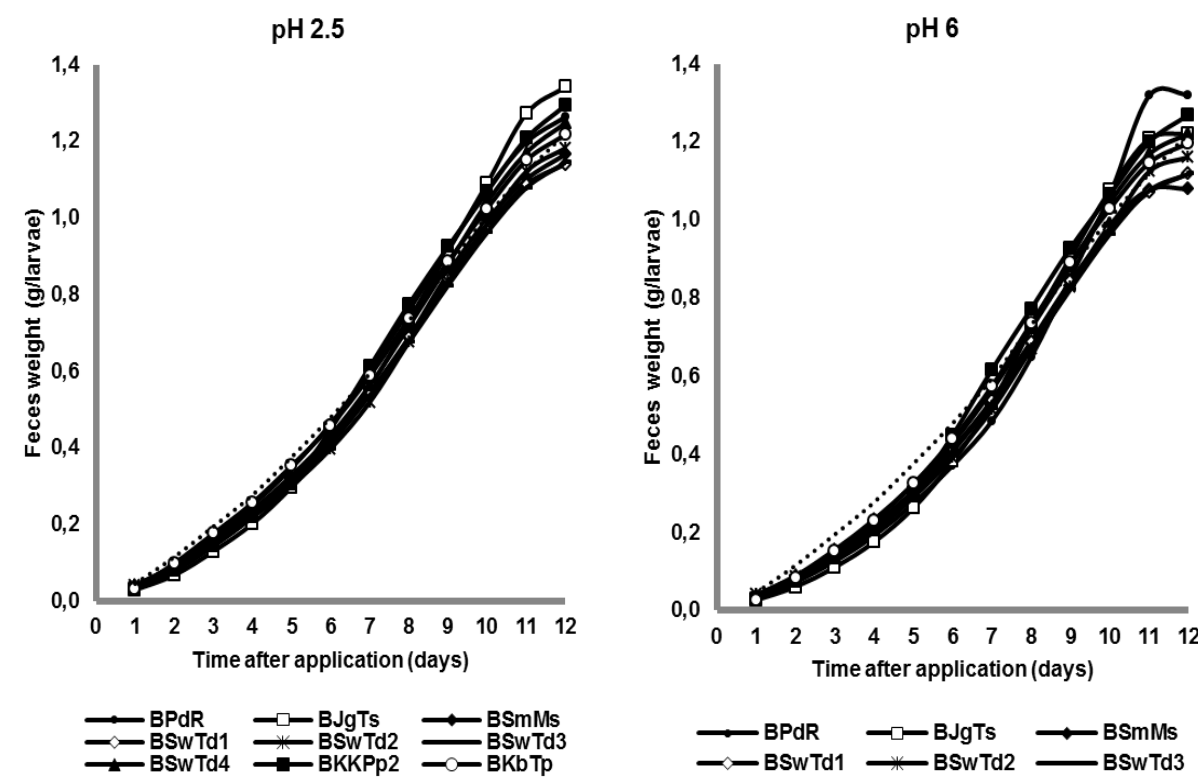

Figure 6. Weight of Spodoptera litura feces

\section{Discussion}

The data showed that the culture filtrates of B. bassiana from PDB with pH 6 caused mortality of $S$. litura larvae which was higher than the mortality resulted from the culture filtrates of PDB at $\mathrm{pH} 2.5$. In this study, the culture filtrate produced from the separation of liquid $B$. bassiana culture from its spores was toxic and lethal on larvae of test insects. According to Pinnamaneni et al. (2010) incubation of test fungi in liquid medium produces exochitinase enzyme and the chitinolytic exochitinase enzyme, able to degrade cuticle insects. Based on the resulting mortality,

the culture filtrates of $B$. bassiana from medium of PDB ( $\mathrm{pH}$ 6) were more toxic than that of $\mathrm{pH} 2.5$. The $\mathrm{pH}$ range for chitinase activity of $B$. bassiana was $\mathrm{pH} 4-6$. More acidic or alkaline nature lowers the activity of culture media (Pinnamaneni et al. 2010). In addition, the $\mathrm{pH}$ of culture media less than 3 is less ideal for the growth and viability of spores of $B$. bassiana (Rizkie et al. 2017). The most ideal $\mathrm{pH}$ to produce the $B$. bassiana spores is the $\mathrm{pH}$ 5.2 (Pham et al. 2009). The liquid media with a pH less than 3 can cause a decrease in the density and viability of B. bassiana spores (Pham et al. 2009; Rizkie et al. 2017). 


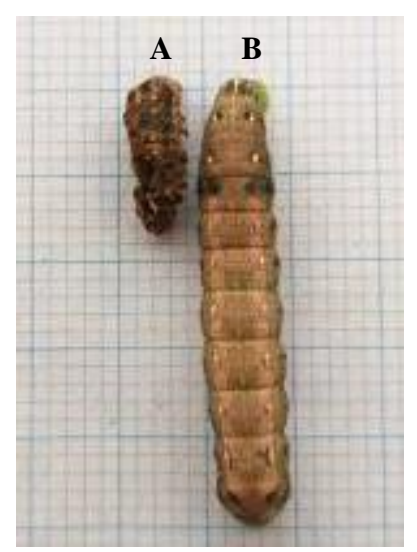

Figure 7. The dead larvae of Spodoptera litura caused by Beauveria bassiana culture filtrate (a) and the healthy one (b)

This study found that the culture filtrates of $B$. bassiana derived from PDB medium of $\mathrm{pH} 2.5$ still caused deaths in test larvae. The isolates of BPdR, BJgTs, BSmMs, BSwTd2, BSwTd3, BSwTd4, and BKKPp2 still caused 6.6-13.33\% deaths. This proves that the culture filtrates of the isolates are still toxic. Only the superior isolates are still toxic at $\mathrm{pH}$ below 3; generally, B. bassiana isolates are able to produce insecticidal culture filtrates if the liquid media during culture $B$. bassiana has a $\mathrm{pH}$ of 3 and above (Cheong 2015). Six of the seven toxic isolates were those from wetland soil (peat soils, tidal lowland, and freshwater swamp soil) in South Sumatra which had a $\mathrm{pH}$ below 3 (Safitri et al. 2018), have the potential to survive as saprophytes in low $\mathrm{pH}$ soils. The failure of entomopathogenic fungi to survive as saprophytes in acidic soils, such as soil in peatlands, tidal lowlands, and freshwater swamps spreading across Sumatra, Kalimantan, and Papua can be overcome if the isolates that hold low $\mathrm{pH}$ results of this study applied over there.

In the treatment with culture filtrates of $B$. bassiana from medium of $\mathrm{pH} 6$ or $\mathrm{pH} 2.5$, the area of the eaten leaves decreased as compared to those of the controls which were given only sterile aquadest. The results of this study showed that the culture filtrates of $B$. bassiana could reduce the appetite of $S$. litura. The weight of $S$. litura larvae eating the leaves which were applied with culture filtrates of B. bassiana from $\mathrm{pH} 6$ or $\mathrm{pH} 2.5$ showed a tendency to lose weight on the sixth day, whereas those in the control group on the sixth day until the end of the observation, the larvae weight continued to rise. The decrease in the larvae weight in the culture filtrate treatment resulted from the sick larvae experiencing slowdown growth. The body of the sick larvae continued to decrease in size, shrink, and dried out and finally, they died. The larvae that were sick from eating the leaves applied to culture filtrates showed a difference when compared to the larvae that died from being infected with B. bassiana spores. According to Safitri et al. (2018) and Sumikarsih et al. (2019), the larvae that died as a result of being infected with the entomopathogenic fungus spores showed symptoms such as the body decreasing in size, shrinking, drying, and having no smell; however, from the host insect's body grew the fungus in the form of mycelia, hyphae and spores on the surface of the integument. The non-growth of $B$. bassiana in larvae of this study resulted from the loss of mycelia, hyphae, and spores in the culture filtrate. Consequently, the death of larvae caused by the toxic compounds contained in the culture filtrate $B$. bassiana did not result from the infection with $B$. bassiana spores.

The color of the culture filtrate at $\mathrm{pH} 6$ culture medium was browner than the that of $\mathrm{pH} 2.5$. According to Qazi (2008), $\mathrm{pH}$ can change the color of culture filtrate because it affects B. bassiana in releasing protease enzymes and influencing toxin production (Sharma et al. 1992). The protease of $B$. bassiana enzyme functions to dissolve insect body proteins and kill them (Mancillas-Paredes et al. 2019). The optimal $\mathrm{pH}$ can cause the fungus to release ammonia and citrate which can increase activity of extracellular enzymes (Khachatourians et al. 2007). Therefore, the data of this study showed that the isolates at pH 6 were browner and caused mortality of S. litura larvae to be higher than those of $\mathrm{pH} 2.5$ due to the more toxic culture filtrate.

The results of this study conclude that the culture filtrates B. bassiana of the liquid medium at $\mathrm{pH} 6$ are more toxic against the larvae of the $S$. litura than those at $\mathrm{pH} 2.5$. Still, an important finding was found that the culture filtrates of isolates of BPdR, BJgTs, BSmTd2, BSwTd3, BSwTd4, and BKKPp2 from $\mathrm{pH} 2.5$ media still had high toxicity against the larvae. These isolates have the potential to survive and settle on low $\mathrm{pH}$ soils. Therefore, these isolates have the opportunity to be successfully utilized in low $\mathrm{pH}$ ecosystems, such as peatlands, tidal lowlands, and freshwater swamps in Indonesia.

\section{ACKNOWLEDGEMENTS}

This research was funded by the scheme of Applied Research (Riset Terapan) with budget year of 2019 according to Directorate of Research and Community Service (DRPM), Directorate General for Research and Development, Indonesian Ministry of Research, Technology, and Higher Education, Contract Number: 211/SP2H/LT/DRPM/IV/2019. This research was chaired by Siti Herlinda.

\section{REFERENCES}

Bugeme DM, Maniania NK, Knapp M, Boga HI. 2008. Effect of temperature on virulence of Beauveria bassiana and Metarhizium anisopliae isolates to Tetranychus evansi. Exp Appl Acarol 46: 275285.

Cheong P. 2015. Bioactive Metabolites of an Isolate of the Entomopathogenic Fungus Beauveria bassiana. Lincoln University, USA.

Dohong A, Aziz AA, Dargusch P. 2018. Carbon emissions from oil palm development on deep peat soil in Central Kalimantan Indonesia. Anthropocene 22: 31-39.

Herlinda S. 2010. Spore density and viability of entomopathogenic fungal isolates from Indonesia, and their virulence against Aphis gossypii Glover (Homoptera: Aphididae). Trop Life Sci Res 21: 11-19. 
Herlinda S, Rizkie L, Suwandi, Susilawati, Lakitan B, Verawaty M, et al. 2018a. Effects of high temperature and ultraviolet-C irradiance on conidial viability and density of Beauveria bassiana and Metarhizium anisopliae isolated from soils of lowland ecosystems in Indonesia. Eurasian J Anal Chem 13: 209-216.

Herlinda S, Yudha S, Thalib R, Khodijah, Suwandi, Lakitan B, et al. 2018 b. Species richness and abundance of spiders inhabiting rice in fresh swamps and tidal lowlands in South Sumatra, Indonesia. J ISSAAS 24: 82-93.

Johari A, Herlinda S, Irsan C, Pujiastuti Y. 2016. Phenomenon of Thrips (Thysanoptera) attack on chili plant (Capsicum annuum). Am J Agric Biol Sci 11: 103-109.

Johari A, Herlinda S, Pujiastuti Y, Irsan C, Sartiami D. 2014 Morphological and genetic variation of Thrips parvispinus (Thysanoptera : Thripidae) in chili plantation (Capsicum annuиm L .) in the lowland and highland of Jambi Province, Indonesia. Am J Biosci 2: 17-21.

Kartika K, Lakitan B, Wijaya A, Kadir S, Widuri LI, Siaga E. 2018 Effects of particle size and application rate of rice-husk biochar on chemical properties of tropical wetland soil, rice growth and yield. Austr J Crop Sci 12: 817-826.

Khachatourians GG, Qazi SS, Reid WR. 2007. Biochemistry and molecular biology of entomopathogenic fungi. In: Brakhage AA, Zipfer PF (eds.). The Mycota VI: Human and animal relationships. Springer-Verlag, Berlin.

Kodir KA, Juwita Y. 2016. Morphological characterization and inventory of local wetland rice collected from South Sumatra Province. Bul Plasma Nutfah 22: 101-108.

Mancillas-Paredes JM, Hernández-Sánchez H, Jaramillo-Flores ME, and García-Gutiérrez C. 2019. Proteases and chitinases induced in Beauveria bassiana during infection by Zabrotes subfasciatus. Southwestern Entomologist 44(1): 125-137.

Marlina N, Asmawati, Zairani FY, Midranisiah, Aryani I, Kalasari R. 2016. Biofertilizer utilization in increasing inorganic fertilizer efficiency and rice yield at c-type flooding land of Tanjung Lago Tidal Lowland. Intl J Engg Res Sci Tech 5: 74-83.

Mulyani A, Sarwani M. 2013. The characteristics and potential of sub optimal land for agricultural development in Indonesia. J Sumberdaya Lokal 7: 47-55. [Indonesian].

Pham TA, Kim JJ, Kim SG, Kim K. 2009. Production of blastospore of entomopathogenic submerged batch culture. Mycobiology 37: 218224.

Pinnamaneni R, Kalidas P, Rao KRSS. 2010. Cloning and expression of Bbchit1 gene of Beauveria bassiana. Open Entomol J 4: 30-35.

Qazi SS. 2008. Regulatory role of ambient $\mathrm{pH}$ in the expression of pathogenicity determinant gene products of Beauveria bassiana and Metarhizium anisopliae. [Dissertation]. University of Saskatchewan, Saskatchewan.

Rizkie L, Herlinda S, Suwandi, Irsan C, Susilawati, Lakitan B. 2017. Conidial density and viability of Beauveria bassiana and Metarhizium anisopliae grown on the low-pH in vitro medium. J HPT Trop 17: 119-127. [Indonesia].

Safitri A, Herlinda S, Setiawan A. 2018. Entomopathogenic fungi of soils of freshwater swamps, tidal lowlands, peatlands, and highlands of South Sumatra, Indonesia. Biodiversitas 19: 2365-2373.

Sharma S, Agarwal GP, Rajak RC. 1992. Effect of temperature, $\mathrm{pH}$ and light on toxin production by Beauveria bassiana (Bal) Vuill. Indian J. Exp. Biol. 30: 918-919.

Sumikarsih E, Herlinda S, Pujiastuti Y. 2019. Conidial density and viability of Beauveria bassiana isolate from Java and Sumatra and their virulence against Nilaparvata lugens at different temperatures. Agrivita J Agric Sci 41: 335-349.

Utami SNH, Maas A, Radjagukguk B, Purwanto BH. 2009. Nature on soil physical, chemical and FTIR spectrophotometry of hydrophobic peat from Central Kalimantan. J Trop Soils 14: 159-166.

Widuri LI, Lakitan B, Hasmeda M, Sodikin E, Wijaya A, Kartika K, et al. 2017. Relative leaf expansion rate and other leaf-related indicators for detection of drought stress in chili pepper (Capsicum annuиm L .). Aust J Crop Sci 11: 1617-1625. 